\title{
A Clinical Study of Kerosene Poisoning Among Children in a Rural Medical College Hospital
}

\author{
Mohammed Anees Ur Rahman', Mohammed Nayaz Ahmed², Ananda Kumar T S², Kumar G V \\ ${ }^{1}$ Assistant Professor of Paediatrics Sri Siddhartha Medical College, Sri Siddhartha Academy of Higher Education Tumkur, Karnataka, India. PIN- 572107, ${ }^{2}$ Professor of \\ Paediatrics Sri Siddhartha Medical College, Sri Siddhartha Academy of Higher Education Tumkur, Karnataka, India. PIN- 572107.
}

\section{Abstract}

Background: Acute poisoning in children adversely impacts on global child health and the patterns and morbidity of poisoning vary across different geographic regions due to variable cultural, social, economic, and geographic factors. Kerosene Poisoning is an important and preventable cause of morbidity and mortality in the developing world. Kerosene is a hydrocarbon product of petroleum distillate, made up of paraffin and naphthalenes. Subjects \& Methods: The complications of kerosene poisoning include hypoxia, pneumonitis, bacterial pneumonia, pneumatocele, pleural effusion, pneumothorax, subcutaneous emphysema and empyema. The usual gastrointestinal symptoms of kerosene poisoning are abdominal pain, vomiting and diarrhoea. Its Central Nervous System manifestations include drowsiness and convulsions. Results: Out of 22 children with kerosene poisoning $18(81.81 \%)$ were male and $4(18.18 \%)$ were female. There was only one case $(4.54 \%)$ of kerosene poisoning with less than one year, between $1-5$ years there were $19(86.36 \%)$ cases and above 6 years there were 2 $(9.09 \%)$ cases of kerosene poisoning. There were $11(50 \%)$ cases were seen during summer followed by $6(27.27 \%)$ cases seen in monsoon and there were $5(22.72 \%)$ cases in winter season. Toddler age, children from rural area, summer season was found major risk factors in our study for kerosene ingestion and is mostly due to improper storage of kerosene. Respiratory complaints like cough and dyspnoea are the two most common symptoms in kerosene poisoning. Conclusion: There is a need to create public awareness regarding kerosene oil storage and accessibility at home from the younger children.

Keywords: Poisoning, Kerosene, Aspiration, Children.

Corresponding Author: Dr. Kumar G V, Professor of Paediatrics Sri Siddhartha Medical College, Sri Siddhartha Academy of Higher Education Tumkur, Karnataka, India. Pin- 572107.

Received: December 2019

Accepted: December 2019

\section{Introduction}

Acute poisoning in children adversely impacts on global child health and the patterns and morbidity of poisoning vary across different geographic regions due to variable cultural, social, economic, and geographic factors. Globally more than one million children die following injuries every year ${ }^{[1]}$ and poisoning is identified as the fourth leading cause of injury related mortality in children [2]. Children younger than five years have the highest risk for acute poisoning ${ }^{[3]}$ while the majority of them belong to either lower or middle income countries ${ }^{[2]}$. Kerosene is aliphatic hydrocarbon obtained from fractional distillation of petroleum. It has low surface tension, low viscosity ${ }^{[4]}$, liquid at room temperature ${ }^{[5]}$, pale yellow or colourless, odourless, and density $0.78-0.81 \mathrm{~g} / \mathrm{cm}^{3}{ }^{[6]}$ Kerosene is a hydrocarbon product of petroleum distillate, made up of paraffin and naphthalenes. In developing countries kerosene is commonly kept in the home, being extensively used for cooking, heating, and lighting. Consequently, accidental kerosene ingestion is often seen in children.

Kerosene is a hydrocarbon which still remains as a major fuel used for cooking in rural India. The huge subsidy the Government provides makes it an economical alternative to LPG. Kerosene is usually stored in any household container and is easily accessible to children. Kerosene Poisoning is an important and preventable cause of morbidity and mortality the developing world ${ }^{[7,}{ }^{8]}$.Ingestion of large quantity of kerosene is rare because of its foul smell and taste. Aspiration of kerosene usually occurs during swallowing and even $1 \mathrm{ml}$ of kerosene aspiration may be associated with pulmonary complications and sometimes death ${ }^{[9]}$. Low viscosity of kerosene enhances penetration into distal alveoli. Low surface tension facilitates spread over a large area of lung tissue. Experimental toxicological studies have shown that aspirated, and not the ingested, kerosene affects the respiratory system. Signs and symptoms of respiratory involvement appear within 30 minutes after aspiration and progress during the first 1-2 days and then subside in the following one to two weeks ${ }^{[10]}$. The complications of kerosene poisoning include hypoxia, pneumonitis, bacterial pneumonia, pneumatocele, pleural effusion, pneumothorax, subcutaneous emphysema and empyema [11, 12]. The usual gastrointestinal symptoms of kerosene poisoning are abdominal pain, vomiting and 


\section{Rahman et al; Terasene Paisaning Amang Children}

diarrhoea. Its Central Nervous System manifestations include drowsiness and convulsions. The aim of the study is to analyze the clinical profile of children admitted with kerosene poisoning in a rural Medical College Hospital.

\section{Subjects and Methods}

A prospective study was conducted in the department of paediatrics Sri Siddhartha medical college, Tumkur, from May 2014 to April 2017 for a period of 3 years.

\section{Inclusion Criteria}

All the children with history of kerosene poisoning which were admitted in the department of paediatrics were included in the study,

\section{Exclusion Criteria}

Poisoning with other household chemicals, plants, pesticides, and medicines, food poisoning and children with doubtful poisoning with kerosene oil were excluded from the study.

A detailed history was taken emphasising on the nature of poisoning, circumstances leading to poisoning, socioeconomic status of the parents, education of the parents, religion, mode of poisoning, seasonal variation, type of family, time-lapse between the consumption of poison and reporting to the hospital and any treatment given before coming to the hospital was noted. A thorough physical examination was done to assess the child for complication of the kerosene poisoning. Investigations were done if necessary. All the details of the kerosene poisoned children were entered in a pre-formed proforma and the data was statistically analysed.

\section{Results}

During the study period there were 22 children admitted with kerosene poisoning. All the 22 children were hospitalized in Paediatric Intensive Care Unit. Out of 22 children with kerosene poisoning 18 $(81.81 \%)$ were male and $4(18.18 \%)$ were female. There was only one case $(4.54 \%)$ of kerosene poisoning with less than one year, between 1-5 years there were $19(86.36 \%)$ cases and above 6 years there were $2(9.09 \%)$ cases of kerosene poisoning. (Table-1)

Table 1: Distribution of kerosene poisoning in children with respect to age and sex

\begin{tabular}{|l|l|l|l|}
\hline Age group & Male & Female & Total \\
\hline Less than 1 year & 1 & 0 & 1 \\
\hline 1-5 years & 15 & 4 & 19 \\
\hline More than 5 years & 2 & 0 & 2 \\
\hline Total & 18 & 4 & 22 \\
\hline
\end{tabular}

Out of total 22 cases $21(95.45 \%)$ were due to accidental ingestion of kerosene and $1(4.54 \%)$ case was due to suicidal attempt. There was a seasonal variation in kerosene poisoning. There were $11(50 \%)$ cases were seen during summer followed by $6(27.27 \%)$ cases seen in monsoon and there were $5(22.72 \%)$ cases in winter season.

Cough was the commonest symptom at the time of presentation, followed by odour, fever, breathlessness and chest signs. [Table-2].

Table 2: Clinical features of kerosene poisoning at the time of presentation

\begin{tabular}{|l|l|l|}
\hline Sl. no & Clinical features & $\mathbf{N}(\mathbf{\%})$ \\
\hline 1 & Fever & $12(54.54)$ \\
\hline 2 & Odour & $13(59.09)$ \\
\hline 3 & Cough & $17(77.27)$ \\
\hline 4 & Breathlessness & $11(50.00)$ \\
\hline 5 & Vomiting & $06(27.27)$ \\
\hline 6 & Convulsions & $01(4.54)$ \\
\hline 7 & Drowsiness & $02(9.09)$ \\
\hline 8 & Chest signs & $08(36.36)$ \\
\hline 9 & Abnormal movements & $01(4.54)$ \\
\hline 10 & Asymptomatic & $01(4.54)$ \\
\hline
\end{tabular}

Majority of children $11(50.00 \%)$ cases were admitted to the hospital within 2-5 hours after consumption of kerosene. About $8(36.36 \%)$ cases were admitted to the hospital within 1-2 hours after consumption of kerosene. About 5 (22.72\%) children came to the hospital by 1-2 hours after kerosene ingestion. The duration of the hospital stay was about 1-2 days in $11(50 \%)$ children with kerosene ingestion. [Table-3].

Table 3: Comparison between duration of hospital stay and time lapse between consumption of kerosene and admission to hospital

\begin{tabular}{|l|l|l|l|l|}
\hline $\begin{array}{l}\text { Duration } \\
\text { of } \\
\text { hospital } \\
\text { stay }\end{array}$ & 1-2 days & 3-4days & 5-6days & Total \\
\hline $\begin{array}{l}\text { Less than 1 } \\
\text { hour }\end{array}$ & $3(13.63 \%)$ & 0 & 0 & $3(13.63 \%)$ \\
\hline $1-2$ hours & $5(22.72 \%)$ & $4(18.18 \%)$ & $1(04.54 \%)$ & $10(45.45 \%)$ \\
\hline $3-5$ hours & $3(13.63 \%)$ & $4(18.18 \%)$ & $1(04.54 \%)$ & $8(36.36 \%)$ \\
\hline 6-10 hours & 0 & 0 & $1(04.54 \%)$ & $1(04.54 \%)$ \\
\hline Total & $11(50.00 \%)$ & $8(36.36 \%)$ & $3(13.63 \%)$ & $22(100.00 \%)$ \\
\hline
\end{tabular}

About $20(90.90 \%)$ children improved and discharged home without any complications. Two $(09.09 \%)$ children were discharged against medical advice. There was no mortality among the children who have consumed kerosene during the hospital stay.

\section{Discussion}

Kerosene poisoning remains as a serious cause of morbidity and occasional mortality in rural India.Children are very vulnerable and the paediatric population below the age of five years constitute about $15 \%$ of unintentional poisoning related deaths. ${ }^{[1,2]}$ The children are inquisitive and often are poisoned accidentally when they ingest them orally.

In the present study $81.81 \%$ children were male and $18.18 \%$ children were female. In a study conducted by 


\section{Rahman et al; Terasene Paisaning Amang Children}

Kumaravel, et al $64 \%$ children with kerosene poisoning were male and $36 \%$ children were female. ${ }^{[13]}$ In the present study $50 \%$ cases were seen during summer followed by $27.27 \%$ cases seen in monsoon and there were $22.72 \%$ cases in winter.In a study conducted by Kumaravel, et al $27 \%$ of the kerosene poisoning were seen in January to march, $31 \%$ of the cases seen in April to June, 22\% of the cases were seen July to September and $20 \%$ of the cases seen in October to December. ${ }^{[13]}$ In a study conducted by Anwar S et al, $71 \%$ of the cases were seen in April to June followed by $29 \%$ of the cases seen in January to march. ${ }^{[9]}$ In the present study $86.36 \%$ were seen in 1-5 year age group. Similar results were seen in a study conducted by Sunilkumar MN et al, ${ }^{[14]}$ which showed, $93.4 \%$ and Singh et $\mathrm{al}^{[15]}$ showed $71.6 \%$ of the cases seen in $1-5$ year age group.

\section{Conclusion}

Toddlers are more vulnerable to kerosene poisoning.Toddler age, children from rural area, summer season was found major risk factors in our study for kerosene ingestion and is mostly due to improper storage of kerosene.Respiratory complaints like cough and dyspnoea are the two most common symptoms in kerosene poisoning.Harmful effects of traditional first aid practices prevalent among rural populations are detrimental to health of the child and the majority is unaware of these adverse effects. There is a need to create public awareness regarding kerosene oil storage and accessibility at home from the younger children.

\section{References}

1. Bronstein AC, Spyker DA, Cantilena LR. GreenJL,Rumack BH, Heard SE. "2007Annual report of theAmerican Association of Poison Control Centers' National Poison Data System (NPDS): 25th annual report," Clinical Toxicology, vol. 46, no. 10, pp. 927-1057, 2008.

2. A. A. Hyder, S. Wali, S. Fishman, and E. Schenk, "The burden of unintentional injuries among the under-five population in South Asia," ActaPaediatrica, vol. 97, no. 3, pp. 267-275, 2008.

3. J. B. Mowry, D. A. Spyker, L. R. Cantilena Jr., J. E. Bailey, andM. Ford, "2012 Annual Report of the American Association ofPoison Control Centers' National Poison Data System (NPDS):30th Annual Report.," Clinical toxicology (Philadelphia, Pa.),vol. 51, no. 10, pp. 949-1229, 2013.

4. KrishanVij, Textbook of Forensic Medicine and Toxicology Principles and Practice, Sixth Edition, Elsevier, A division of Reed Elsevier India Private Limited, 2014; P- 516.

5. GautamBiswas, Review of Forensic Medicine and Toxicology, Fourth Edition, Jaypee Brothers Medical Publishers, 2019; P- 637.

6. Dr. P. V. N. R. Prasad. Illustrated AgadaTantra, Third Edition, Chowkhamba Sanskrit Series Office Varanasi, 2016; P-345.

7. Meyer S, McAdams AJ, Hug G. Unintentional householdpoisoning in children. KlinPadiatr. 2007;219:254-260.

8. Shiamo W, Bucurales JC, Balistreri WF. Paraffin (kerosene)* poisoning in under-five children: a problem of developing countries. Int J NursPract. 2009;15:140-44.

9. Anwar S, Clinical Profile of Kerosene Poisoning in a Tertiary Level Hospital in Bangladesh. Bangladesh J Child Health. 2014; 38:11-14.

10. Thalhammer GH, Eber E, Zach MS. pneumonitis and pneumatoceles following accidental hydrocarbon aspiration in children. Wien Klein Wochenschr. 2005;117,150-153.

11. Gupta P, Singh RP, Murali MV, Bhargava SK, Sharma P. Kerosene oil poisoning - a childhood menace. Indian Pediatr. 1992;29:979-984.

12. Annobil SH, Ogunbiyi OA. Pulmonary Radiological changes in Kerosene poisoning in the Asir region of Saudi Arabia. Ann Trop Pediatr. 1991;11:391-395.

13. Kumaravel K S, Rameshbabu B. Kerosenepoisoning in childhood: a 3-year retrospective study at a tertiary referralhospital. International Journal of Contemporary Medical Research2016;3(6):1832-1834.

14. Sunilkumar MN, Parvathy VK, Analysis of profile of childhood kerosene poisoning in a tertiary care medical collegehospital: Int J Pediatr Res 2016;3(4):211-217.Doi:10.17511/ijpr.2016.4.01.

15. Singh AK, GurungPK. Factors Contributing to Kerosene Oil Poisoning in Children.JBPKIHS 2018;1(2):65-68.

Copyright: ( $)$ the author(s), 2019. It is an open-access article distributed under the terms of the Creative Commons Attribution License (CC BY 4.0), which permits authors to retain ownership of the copyright for their content, and allow anyone to download, reuse, reprint, modify, distribute and/or copy the content as long as the original authors and source are cited.

How to cite this article: Rahman MAU, Ahmad MN, Ananda KTS, Kumar GV. A Clinical Study of Kerosene Poisoning Among Children in a Rural Medical College Hospital. Asian J. Clin.Pediatr.Neonatol.2019;7(4):35-37.

DOI: dx.doi.org/10.21276/ajcpn.2019.7.4.8

Source of Support: Nil, Conflict of Interest: None declared. 